\title{
THE EFFECT OF PROBLEM-BASED E-LEARNING CONTENT ON THE LEARNING ACHIEVEMENT IN \\ BASIC COMPUTER SYSTEM COURSE (DSK) OF THE STUDENT OF INFORMATICS ENGINEERING EDUCATION DEPARTMENT
}

\author{
I Gede Partha Sindu \\ Jurusan Pendidikan Teknik Informatika Universitas Pendidikan Ganesha \\ partha.sindu@undiksha.ac.id \\ A. A. Gede Yudhi Paramartha \\ Jurusan Manajemen Informatika, Universitas Pendidikan Ganesha \\ yudhi.paramartha@undiksha.ac.id
}

\begin{abstract}
This study was aimed at finding out the difference in learning achievement in basic computer system course (DSK) between the students who learned from content e-problem-based learning in experiment class and those who learned from conventional model in control class in learning basic computer system course. This study used quasi-experimental non-equivalent Pretest Post-test Control Group Design. There were three variables involved in this study. Two of them were independent variable and dependent variable. The independent variable was e-problem-based learning and the dependent variable was learning achievement. Another variable which functioned as covariate was students'prior learning achievement. The population consisted of all students of the first semester in Informatics Engineering Education Department. The sample was selected by using simple group random sampling technique. An essay test was used to know the students'basic computer system learning achievement (DSK). The hypothesis was tested by one-way analysis of co-variance (ANACOVA). The results showed that the mean score in the learning achievement of the students who learned from content e-problem-based learning was higher than that of those who learned from using conventional model. Content e-problem-based learning plays the role in improving students' learning achievement.
\end{abstract}

Keywords: content e-problem-based learning, basic computer system course. 


\section{INTRODUCTION}

Efforts at Improving the quality of education has to be made, and one of the most promising ways is through the use of information technology. At present, the use of information technology such as e-learning is on the increase. The existing e-learning at Ganesha University of Education (Universitas Pendidikan Ganesha/Undiksha) has not been used optimally, although it has supported the learning and assessment processes. The Undiksha's e-learning uses the most popular LMS (Learning Management System) Open Source which is also called Moodle. In terms of the use of the system, Moodle is very good, but it needs to be supported by content we want the learning process to run well. At Informatics Engineering Education Department (PTI), there are many types of courses that need content development to support innovative learning. One of the courses that is suitable to be taught by using the innovative learning is Basic Computer System course (DSK).

DSK is a stage in learning computer science that introduces the students to computer, the basics of computer science, programming, information system, and artificial intelligence. The coverage of the science is very dense in this course, making it difficult for the students to learn the materials. The density of the materials can be seen in the syllabus that covers the development of hardware, software, the use of computer, classification of computers, input equipment, processing equipment, output equipment, external storage, numerical system encode, data communication system and network, basic concepts in structured program development, software, information system, database, method of data processing, and artificial intelligence. The learning process in DSK course will be facilitated with the use of an innovative learning process which can develop further creative thinking ability and critical thinking ability and can attract students to solve learning problems.

According to Santyasa (2011), one of the learning environments which can accommodate the development of problem solving ability of the learners is problem-based learning (PBL). PBL is a learning model which is based on John Dewey's philosophy according to which teachers should encourage students to be involved in the task oriented to problems related to the world of the learners, and the learners should be active in the learning activity. PBL is a learning model that makes problems as the basis of learning. PBL is a model of learning that uses real world problems which are ill-structured as ones of the context for them to learn about critical thinking skills and problem solving skill, and to acquire essential knowledge and concepts for learning materials.

The previous study related to the content development of e-learning for DSK has produced a product in the form of basic computer system learning materials designed by using e-learning media at Undiksha. The results of the e-learning content development in DSK study was then implemented in the classroom to find out differences in learning achievement in DSK between the students who learned by the content e-problem-based learning in the experiment class and those who learned by the conventional model in the control class. This study was motivated by the fact that Informatics Engineering Education Department students who learned basic computer system course in the academic year 2016/2017 had low learning achievements. Thus, this study was conducted to find out a way to improve the situation.

E-learning which was implemented in this study also functioned as a discussion forum between the lecturer and the students, and could also be used as online quizes, so that all activities in the learning process become very effective. Atmanegara (2016) in his study shows that the use of e-learning in the learning process is very effective, because with the availability of the media, the students can access various materials easily. Beside Atmanegara's study, a study conducted by Wijaya (2012) shows that web-based elearning following e-pedagogy principles enhance the students' ability in understanding the material in economics better as shown by an increase in learning achievement.

The present study in the development of e-learning content based on problems for DSK was designed by using eight steps in problem-based learning approach. The eight steps were: (1) finding a problem; (2) defining problem; (3) collecting text; (4) making tentative assumption; (5) investigating; (6) im- 
proving problem that has been defined; (7) concluding alternative to solve problem collaboratively; and (8) testing solutions to the problems. Based on the eight steps, the lecturer plays the role in posing real problems, giving encouragement, motivating, and providing learning material and facilities needed by the students to solve problems. By implementing problem-based e-learning, it is expected that the students use their thinking skill in analyzing problems presented to dig up new information and to use their prior knowledge in solving problems.

Content e problem-based learning for DSK was implemented online. E-problembased learning was designed with a simple requirement, is personal, and speedy. The simple system will facilitate the students in using the technology and the existing menu, with the practicality in the panel provided, it will reduce the introduction of the e-learning system itself. The personal requirement means the lecturer can interact well like in the real communication between the lecturer and the students in the classroom. The more personal approach and interaction applied in eproblem-based learning helps the lecturer to assess the progress in the students' learning, in analyzing and solving problems. Quick response given by the lecturer to students' complaints and their needs is needed to help in making the learning process run well.

\section{METHODS}

This study used quasi-experimental design because not all the variables and condition in the experiment could be managed and controlled tightly, thus this study belongs to a quasi-experimental study type. The design of study was non-equivalent Pretest Post-tes Control Group Design. This design helps in checking the level of similarity between the groups, since the pretest score are closely related to the dependent variable, learning achievement.

The population of the study consisted of all first semester students at Informatics Engineering Education Department in the academic year 2017/2018. The sample was selected through group random sampling technique, that is by selecting the sample randomly. This technique was used as the technique for taking a sample because the individuals of the population had been distributed to classes so that it was impossible to do the random sampling of the individual of the population. The sample used in this study consisted of two classes, namely class $1 \mathrm{~A}$ and class 1C, with 35 students each at Informatics Engineering Education Department. The variables in this study consisted of an independent variable, in this case, the content e-problembased learning, and a dependent variable, in this case, learning achievement. Another variable which functioned as covariate was students' prior knowledge.

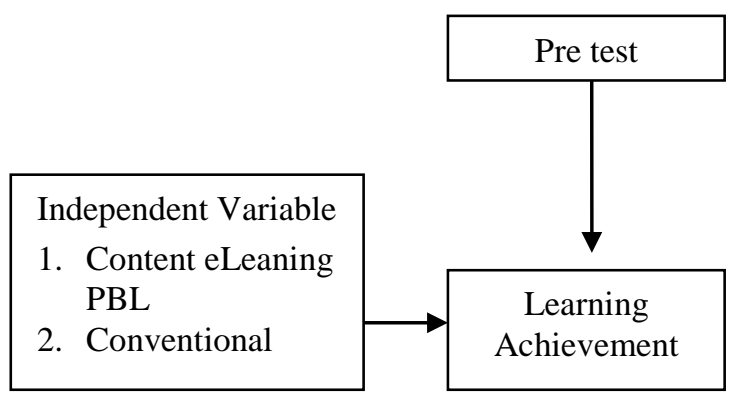

Figure 1. The Relation between Variables in the Study

The steps in this study that were implemented consisted of : (1) orientation and observation of the design and its implementation in the class; (2) designing lesson plans for DSK with content e-problem-based learning in the experimental class and with the conventional model in the control class; (3) doing a try-out test of learning achievement in DSK to make it viable for the study; (4) administering the pre test to each group both the one who would learn from content eproblem-based learning and another one who would learn from conventional model; (5) implementing content e-problem-based learning in the experimental class and conventional model in control class; (6) administering post test to each learning groups both the one learning from content e-problem-based learning and another one learning from conventional model; (7) analyzing data of learning achievement to test whether the hypothesis of the study could be accepted or rejected. The stages of the study conducted can be seen in figure 2 as follows. 


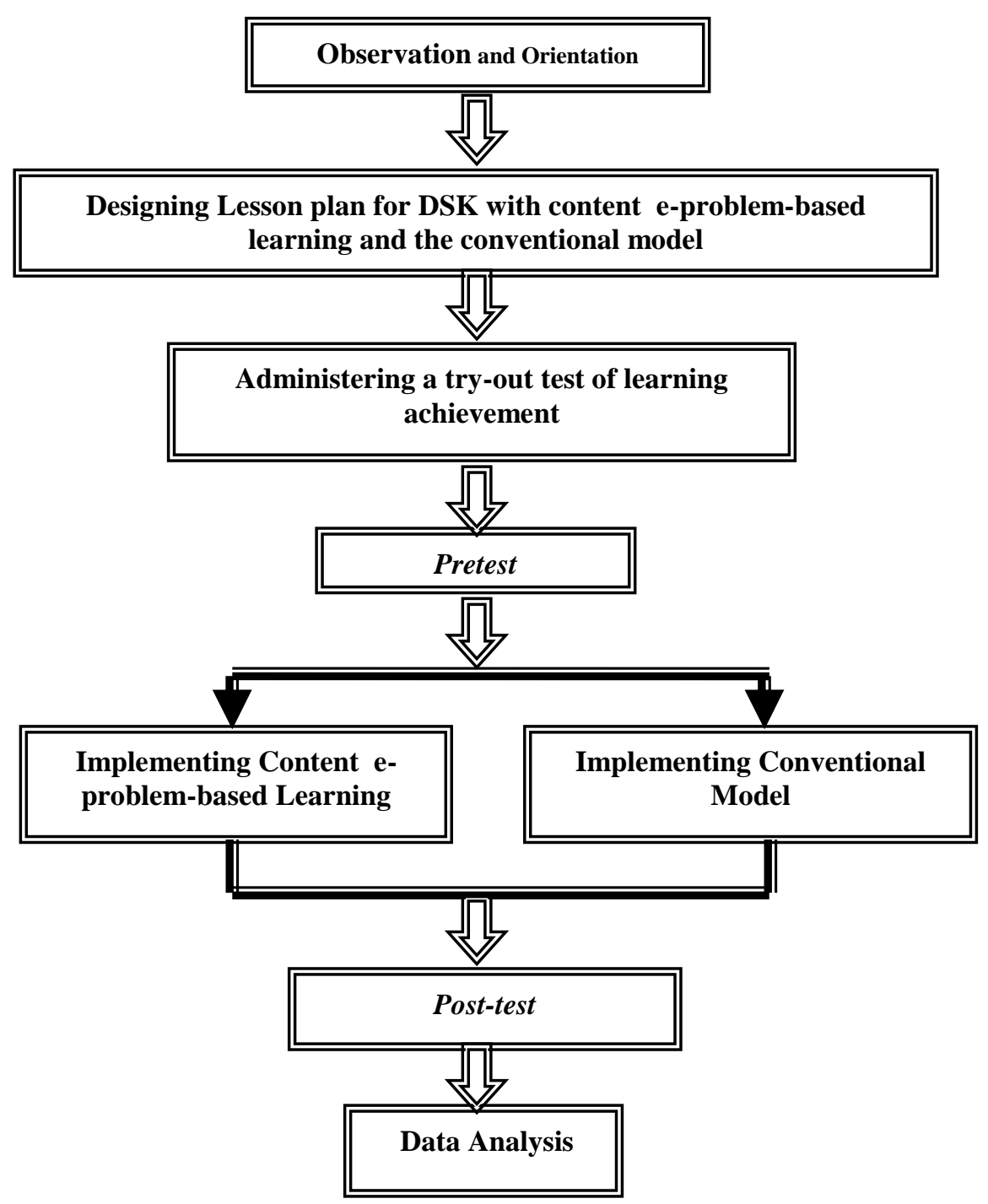

Figure 2. Stages of Study

Before it was used in the study, the instrument was tried-out first. The instrument used in this study was a learning achievement test. The learning achievement test for DSK used was in the form of an essay test. The tryout of the test was aimed at checking the content validity according to content experts and research design experts considerations. The instrument try-out was aimed to check the content validity and describe the degree of estimation specified by item validity and internal reliability. The validation of the test included content validity, construct validity, and item validity. Content validity and construct validity were found by judging the test and in this case two judges or experts were involved. Item validity was done by using 4 statistical tests, consisting of item internal consistency, test reliability, test discriminating index and test difficulty level. To find out the item validity, correlation formula was used. The correlation formula used to test item validity was product moment corelation formula.

Based on the result of the try-out analysis of the instrument, eight out of twenty items were selected and tried-out, in which the variable to be measured through the test in this study was the students' learning achievement problem solution that consisted of application (C3) analysis (C4), synthesis (C5), and evaluation (C6). The data analysis techniques used in this study were descriptive statistics and co-variant analysis (one-way ANACOVA). The descriptive analysis was used to describe the mean score and standard deviation. The mean score and standard deviation described consisted of mean score and standard deviation in the students' learning 
achievement and the students' learning achievement in pre test.

The normality test for data distribution was meant to ascertain that the sample really came from a normally distributed population, so that hypothesis testing could be performed. The normality testing of data distribution was tested by using Kolmogorov-Smirnov statistics test or Shapiro-Wilks test (Candiasa, 2006, p. 2). The criteria for testing the data is that the data was normally distributed if the the level of significance produced was more than 0.05 and in this case the data were not normally distributed.

Variance homogeneity test between groups was also performed to make sure that the difference that occurred in the hypothesis testing was only caused by the difference in the group. To test the variance homogeneity between groups Levene's test of equality or error variance was used (Candiasa, 2004). The criteria for testing included: the data had the same variance (homogeneous) if the level of significant produced more than 0.05 otherwise the variance of the sample was not the same (not homogeneous). For testing the hypothesis, the hypothesis in this study were divided into null hypothesis (Ho) and alternative hypothesis (H1). The hypothesis to be tested are as follows.

$\mathrm{H}_{0}$ : There was not any difference in learning achievement between the students in the group who learned from content eproblem-based learning and the group of students who learned from conventional model.

$\mathrm{H}_{1}$ : There was a difference in learning achievement between the students in the group who learned from content eproblem-based learning and the group of students who learned from conventional model.

The hypothesis testing used $\mathrm{F}$ test through one-way co-variate analysis (ANACOVA). The level of significance of $F$ variance statistics was subjected to co-variate testing or the testing of the inter-subject effect (Candiasa, 2004). If the level of significance smaller than 0.05 , it means that Ho was rejected.

\section{RESULTS AND DISCUSSION}

Problem-based learning implemented in DSK course was designed to develop the students' critical thinking ability in solving problems. The lecturer as facilitator gave the opportunity to the students to solve problems given in a systematical and logical way. Students-centered learning process by implementing problem-based learning was expected to improve the students' learning achievement, especially in DSK. The result of content eproblem-based learning in DSK course has passed the stage of expert judgment and field testing has been carried out in some sample members, which was then continued with the testing of the effect of content e-learning of DSK course of the students' learning achievement. The mean score for the pretest that was given to the students of the Informatics Engineering Education Department in the first semester in 2017 was used as the basis in finding out the level of students' understanding of DSK materials.

In this study, the learning process used content e-problem-based learning in the experimental class and the conventional model in the control class in which the learning achievements were shown to be different for the experimental class and the control class. This finding was obtained based on the result of pretest analysis with the students' mean score in the group who learned from content e-problem-based learning in the experimental class of 7.40 falling into insufficient classification. While the ean score of the students in the group who learned from the conventional model in the control group was 8.11, falling into insufficient classification. The low mean score of the students in the pretest indicated that the students have got the high ability to solve the problems but it still fell into a low category, because the students have not yet understood the whole materials in DSK. The knowledge that has been acquired by the students was limited to the knowledge that they got from daily experiences.

Based on the result of post test analysis (the students' learning achievement) the mean score of the students in the group who learned from content e-problem-based learning in the experimental class was 14.57 falling into sufficient classification while the group who learned from the conventional model in the 
control class was 12.14, falling into insufficient classification. The difference in the mean score in post test in the two groups was caused by the fact that in the group who learned from content e-problem-based learning in the experimental class, the learning process that was implied related the concept learned more to the realistic context or the students' daily experiences, so that the students found it easier to solve problems given by the lecturer. On the other hand, the group who learned from the conventional model in the control class, the learning process presented academic problems that refer to problems in the textbook that contain objects and events unrelated to the reality in the students' daily life, so that it could not motivate the students to think critically and creatively in solving problems. The mean score and the standard deviation in the post test in each unit analyzed are presented in Table 1 .

Table 1. Mean Score and Standard Deviation in Post Test result

\begin{tabular}{lcc}
\hline Group & Mean & $\begin{array}{c}\text { Standard } \\
\text { Deviation }\end{array}$ \\
\hline $\begin{array}{l}\text { Content e-Problem- } \\
\text { Based Learning }\end{array}$ & 14.57 & 3.28 \\
Conventional Model & 12.14 & 12.14 \\
Total & 26.71 & 15.42 \\
\hline
\end{tabular}

Before the testing of hypothesis was performed, requirement tests were done first. The requirement tests that had to be done were: (1) test of data normality; (2) tets of inter-group variance homogeneity. The test of normality of the data was done to all data of the post test results both from the group of students who learned from content e-problembased learning in the experiment group class and those who learned through conventional model in the control class. The recap of the normality test result can be seen in Table 2 .

Table 2 shows that the group who learn through e-content problem-based learning in the experiment class and the conventional model in the control class were normally distributed with Shapiro-Wilk showing a level of significance greater han 0.05 . As the whole the data in the group who learned from content e-problem-based learning in the experimental class and the conventional model in control class were normally distributed.
Table 2. The Recap of the Data Normality Testing

\begin{tabular}{lcccccc}
\hline \multirow{2}{*}{ Model } & \multicolumn{3}{c}{ Kolmogorov-Smirnov } & \multicolumn{3}{c}{ Shapiro-Wilk } \\
\cline { 2 - 7 } & Statistic & $d f$ & Sig. & Statistic & $d f$ & Sig. \\
\hline $\begin{array}{l}\text { Content e- } \\
\text { problem-based } \\
\text { learning }\end{array}$ & 0.152 & 35 & 0.039 & 0.969 & 35 & 0.502 \\
$\begin{array}{l}\text { Conventional } \\
\text { Model }\end{array}$ & 0.132 & 35 & 0.129 & 0.960 & 35 & 0.360 \\
\hline
\end{tabular}

This homogeneity test of variance was done to all data of the post test result based on the grouping of learning model implemented. To test inter-group homogeneity variance Levene's test of Quality of Error Variance. was used.

Table 3. Recap of Test of Homogeneity of Variance

\begin{tabular}{|c|c|c|c|c|c|}
\hline & & $\begin{array}{l}\text { Levene's } \\
\text { Statistic }\end{array}$ & $d f 1$ & $d f 2$ & Sig \\
\hline \multirow{4}{*}{$\begin{array}{l}\text { Learning } \\
\text { achieve- } \\
\text { ment }\end{array}$} & Base on Mean & 2.457 & 1 & 68 & 0.122 \\
\hline & $\begin{array}{l}\text { Based on } \\
\text { Median }\end{array}$ & 2.358 & 1 & 68 & 0.129 \\
\hline & $\begin{array}{l}\text { Based on } \\
\text { Median and } \\
\text { with adjusted df }\end{array}$ & 2.358 & 1 & $\begin{array}{c}57.7 \\
62\end{array}$ & 0.130 \\
\hline & $\begin{array}{l}\text { Based on } \\
\text { trimmed mean }\end{array}$ & 2.509 & 1 & 68 & 0.118 \\
\hline
\end{tabular}

Based on Table 3, the result of the test of homogeneity of variance of the data obtained shows that the level of significance was above 0.05 which means that the intergroup variance was homogeneous.

Based on univariate analysis result, it was obtained that the effect of pretest on the score in learning achievement, $\mathrm{F}$ statistic value $=18.401$ at sig. $=0.001$. This level of significance is lower than 0.05 , which means that there is the effect of pretest on the students' learning achievement. Therefore, the co-variate selected in this study was appropriate. While, for the effect of the content eproblem-based learning in DSK course on learning achievement was obtained $\mathrm{F}$ statistic value $=12.928$ at sig. $=0.001$. This level of significance is smaller than 0.05 , which means that there is the difference in the mean score of learning achievement in the group who learned from content e-problem-based learning and the group who learned from conventional model in DSK course. The recap of ANACOVA result is presented in Table 4. 
Table 4. Recap of ANACOVA Test Result

\begin{tabular}{lccccc}
\hline Source & $\begin{array}{c}\text { Type III Sum of } \\
\text { Squares }\end{array}$ & df & Mean Square & F & Sig. \\
\hline Corrected Model & 188.067 & 2 & 94.034 & 13.560 & .000 \\
Intercept & 240.550 & 1 & 240.550 & 34.687 & .000 \\
Model & 89.653 & 1 & 89.653 & 12.928 & .001 \\
Learning Achievement & 127.610 & 1 & 127.610 & 18.401 & .000 \\
Error & 464.633 & 67 & 6.935 & & \\
Total & 13035.000 & 70 & & & \\
Corrected Total & 652.700 & 69 & & & \\
\hline
\end{tabular}

The finding in this study is in line with the result of the previous studies done by Sindu, Santyasa, \& Warpala (2013) that shows that the learning achievement of the students who learned from e-problem-based learning is higher than that of the group who learned from direct instruc-tion model and Sugandi (2013) which shows that the autonomy in students' learning in Mathematics by using problem-based ap-proach with jigsaw type cooperative setting is better than that of those who used conventional learning model. Assriyanto, Sukardjo, \& Saputro (2014) also shows that the students' cognitive and affective learning achievement who use problembased learning model and guided inquiry method is higher that that of those who learn through experiment method. Theoretically this can also be explained through problems in DSK course which used problems that consisted of objects or elements that consisted of software, hardware, and brain ware often found in the students' everyday life in which problem solving stressed the application of concepts of DSK course. In learning by using content problem-based or problem-based learning, the students did not only memorize the theory but also related the problem with their daily life so that the learning became more meaningful and could develop students motivation to learn. Students in general will be more interested to solve problems with problem-base learning because they feel the problem are related to daily life. therefore the use of the problem in the lecture will make the information conveyed in the lecturer more organized in students' cognitive structure, in which it makes the students memory of the concept became stronger. A better mastery of concept and higher motivation in solving a certain problem will have a positive impact to the students' high level thinking competence. The tendency of students to learn and memorize will cause their weaknesses in a concept and theories which come from the principals and concepts in DSK. This of course will influence the mastery of concept possessed by the students about the element which consist of software, hardware and brain ware.

Although content e-problem-based learning in the experiment class empirically gave a better score than in the conventional model in the control class, content e-problembased learning was not been able to make the students achieve a satisfactory learning achievement. There were some factors which assumed to have caused the less than optimal content e-problem-based learning effect in which the students have not been able to achieve very good category $(85 \%-100 \%)$.

First, the problems presented in the learning process which were usually done by giving the conventional model so that the students have the habit of solving problems by using the conventional model and were not yet used to solving problems presented in the form of problem-based learning. Problem based learning used in this study contained real life problem related to the students' real life differ very much from the problems they found in DSK course before. Before they solved the problem, they had to decide on some points: (1) reviewing and presenting problems; 2) organizing strategies; (3) implementing strategies; and (4) discussing and evaluating result. Thus, the existing problem solving in the e-learning requires hard work to find information that can be used to solve 
problem given. On the other hand, in the conventional model, there was a tendency to require students only to use basic computer system theories that are appropriate to solve the problems so that the students will be motivated only to memorize the theories without understanding them. Thus, conventional model is less helpful for the students in developing their reasoning and their critical and creative thinking competence.

Secondly, the students were not yet used to the essay test used in this study. In evaluation, they had been used to using objective test which only required them to choose one answer given without giving a scientific reason of why they chose it. While in this study the students had to explain their answer by relating the concept in DSK. This could have caused them to feel that they were given very difficult problems without considering the meaning that was intended to be given through the problems.

Thirdly, the level of difficulty of the test given in this study. Based on the result of analysis of the instrument try-out, then eight items selected from twenty items tried-out, in which the variable that was meant to be measured through the test in this study was the one which covered the aspects of application (C3), analysis (C4), synthesis (C5), and evaluation (C6). While the test that was used to be given in DSK before only covered the aspects of knowledge, understanding, application, and analysis, so that the students had problems in doing the test given to determine the students' learning achievement. Thus, in general, the test used in this study needed more complex problem solving to answer all the items given.

Fourthly, the learning system conducted at the Informatics Engineering Education Department in Undiksha still used conventional system in which the students only listen to the explanation given by the lecturers.

Efforts made to solve the problems above include: first to give exercises in solving problems based on contextual problem or types of problems related to the students' daily experience. At every meeting in the process of learning, to give a description of problem that is easy to understand, and to give a realistic explanation to every question asked by the students or material that has not been understood by the students. Secondly, to give a guide to each group at the time of discussion activity in cooperative group, so that the discussion activity in the group can run more optimally.

The result of this study is $\mathrm{n}$ line with the result of the study conducted by Raharjo \& Soenarto (2015) that problem-based learning model is very effective in improving students' learning achievement for the students with low level of creativity. Based on the result of the students conducted by Nafiah \& Suyanto (2014), problem-based learning can improve students critical thinking skill. The result of study is related to the one done by Sofyan \& Komariah (2016) that problem based learning can also be implemented both for simple and complex material and can support the implementation of the 2013 Curriculum. The finding of this study has the following implications: first, the mean score of students who learned from content eproblem-based learning was higher than that of the students who learned from the conventional model. Thus, the use of problem solving in learning process results in a better learning achievement. Secondly, the means of the students' learning achievement of those who learned from content e-problem-based learning falls into a higher category than the mean score of the group learning from the group learning from the conventional model. Therefore, problem-based learning model plays a role in improving students learning achievement.

\section{CONCLUSION}

Based on the result of the study and discussion, it can be concluded as follows. There is a significant difference in learning achievement between the group of students who learned from content e-problem-based learning in the experimental class and the group of students who learned from the conventional model in the control class. The mean score of the group of students who learned from e-problem-based learning in the experimental class is higher than that of the group of the students who learned from the conventional model in the control class. Thus, problem-based learning model plays the role in improving students' learning achievement.

Based on the result and discussion, some suggestions can be made to improve the 
quality of learning. Since content e-problembased learning is able to create a more conducive and meaningful learning atmosphere, and able to lead students in improving their learning achievement, then it is suggested to the lecturers to adopt content problem-based learning and use it in learning activities in the classroom. In addition to learning through the use of learning model, there are still other variables which influence the students' learning achievement, thus it is suggested that the practitioners should always consider and find other factors that can influence the level of earning achievement, for example, learning motivation.

\section{REFERENCE}

Assriyanto, K. E., Sukardjo, J. S., \& Saputro, S. (2014). Pengaruh model pembelajaran berbasis masalah melalui metode eksperimen dan inkuiri terbimbing ditinjau dari kreativitas siswa pada materi larutan penyangga di SMA N 2 Sukoharjo tahun ajaran 2013/2014. Jurnal Pendidikan Kimia, 3(3).

Retrieved from http://jurnal.fkip.uns.ac.id/index.php/kim $\mathrm{ia/article/view/4268}$

Atmanegara, W. P. (2016). Pengembangan media pembelajaran elearning menggunakan edmodo pada mata pelajaran elektronika dasar studi pada siswa kelas X TEI SMK Negeri 2 Bojonegoro. Jurnal Pendidikan Teknik Elektro, 5(1), 359-364. Retrieved from http://ejournal.unesa.ac.id/ article/17942/44/article.pdf

Candiasa, I. M. (2004). Statistik multivariat dilengkapi aplikasi dengan SPSS. Singaraja: Unit Penerbitan IKIP Negeri Singaraja.

Candiasa, I. M. (2006). Program SPSS. (buku ajar, tidak diterbitkan). Singaraja: Jurusan Ilmu Keolahragaan, Undiksha.

Nafiah, Y. N., \& Suyanto, W. (2014). Penerapan model problem-based learning untuk meningkatkan keterampilan berpikir kritis dan hasil belajar siswa. Jurnal Pendidikan Vokasi,
4(1). Retrieved from

https://journal.uny.ac.id/index.php/jpv/ar ticle/view/2540/2098

Raharjo, H., \& Soenarto. (2015). Pengaruh metode problem-based learning dan direct teaching terhadap hasil belajar alat ukur. Jurnal Pendidikan Vokasi, 5(2).

Retrieved from https://journal.uny.ac.id/index.php/jpv/ar ticle/viewFile/6383/5516

Santyasa, I. W. (2011). Pembelajaran inovatif. Buku ajar. Singaraja: Universitas Pendidikan Ganesha.

Sindu, I. G. P., Santyasa, I. W., \& Warpala, I. W. S. (2013). Pengaruh model eLearning berbasis masalah dan motivasi belajar terhadap hasil belajar KKPI siswa kelas $X$ di SMK Negeri 2 Singaraja. Jurnal Teknologi Pembelajaran, 3. Retrieved from

http://pasca.undiksha.ac.id/ejournal/inde x.php/jurnal_tp/article/view/617

Sofyan, H., \& Komariah, K. (2016). Pembelajaran problem based learning dalam implementasi Kurikulum 2013 di SMK. Jurnal Pendidikan Vokasi, 6(3), 260-271. https://doi.org/10.21831/jpv.v6i3.11275

Sugandi, A. I. (2013). Pengaruh pembelajaran berbasis masalah dengan setting kooperatif Jigsaw terhadap kemandirian belajar siswa SMA. Jurnal Ilmiah Program Studi Matematika STKIP Siliwangi Bandung, 2(2), 144-155. Retrieved from http://www.ejournal.stkipsiliwangi.ac.id/ index.php/infinity/article/view/31

Wijaya, M. (2012). Pengembangan model pembelajaran elearning berbasis web dengan prinsip epedagogy dalam meningkatkan hasil belajar. Jurnal Pendidikan Penabur, 19(11), 20-37. Retrieved from http://bpkpenabur.or.id/wpcontent/uploads/2015/10/jurnal-No19Thn11-Desember2012.pdf\#page $=26$ 